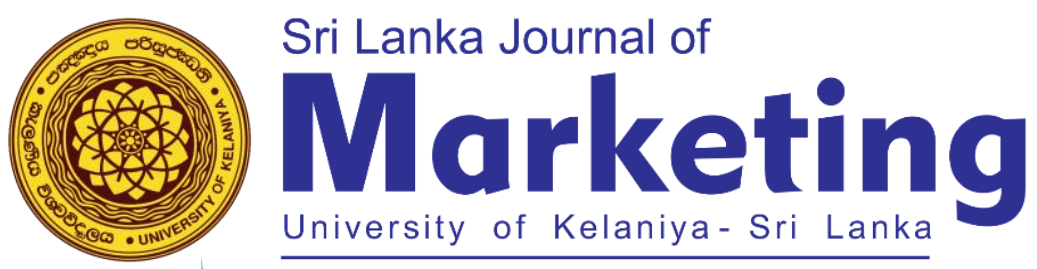

\title{
Factors Influencing Millennials' Adoption on Internet Banking, Propositions Through Refined UTAUT2
}

\author{
Thilina DK \\ Senior Lecturer, University of Kelaniya, Sri Lanka \\ thilinasq@kln.ac.lk \\ Bandara B. S.S. U. \\ Senior Lecturer, University of Kelaniya, Sri Lanka \\ saumya.uditha@kln.ac.lk
}

DOI: http://doi.org/10.4038/sljmuok.v7i3.72

\begin{abstract}
This concept paper aims to conceptualize internet banking adoption in the Sri Lankan context with special reference to Undergraduates. Even though the rapid spread of technology has made the internet the best channel to provide banking services, it is explored in many studies that the internet adoption rate in Sri Lanka is at an inadequate level. This paper primarily focusses on millennial internet banking consumption, which is intended to study through a sample of Undergraduates in Sri Lanka. Although there are numerous studies carried out by different researchers on the internet banking context, the attention given to millennial internet banking behavior is insufficient. The review is based on the theoretical rationale based on the extension to Unified Theory of Acceptance and Use of Technology (UTAUT2), which mainly incorporates purchasing determinants (performance expectancy, effort expectancy, social influence, price value, habit, and facility conditions) and supportive empirical findings. A descriptive statistical review shows why Sri Lanka is considered a context to be examined while empirical evidence supports the arguments. The paper concludes with research propositions to examine factors that influence the adoption of internet banking.
\end{abstract}

Keywords: Behavioral Adoption, Internet Banking, Purchase Intention, UTAUT

ORCID of authors: Thilina DK. - (D) https://orcid.org/0000-0003-1585-305X

Bandara B. S.S. U. - (D) https://orcid.org/0000-0002-9162-9466

Copyright: This is an open access article distributed under the Creative Commons Attribution License 4.0, which permits unrestricted use, distribution, and reproduction in any medium, provided the original work is properly cited. 


\section{INTRODUCTION}

\subsection{Background of the Study}

Online banking is a modern delivery channel for banking services. The definition of online banking varies among researchers partially because online banking refers to several types of service through which bank customers can request information and carry out most retail banking services via computer, telephone, or mobile phone. Online banking has changed the way of services provided by the banking sectors to their customers (Madumanthi \& Nawaz, 2016). The purpose of providing online banking is to reduce the physical distance between modern world customers and banks (Seelanatha, 2010).

Internet banking activities are more popular than traditional banking activities with the advancement of new technology in the banking sector. Furthermore, it results from the evolution of new technology that reduces the physical distance between modern world customers and banks. Internet banking uses the internet as the delivery channel to conduct numerous operational activities \& deliver services to customers. On the one hand, Internet banking contributes to increased banking system efficiency and provides more convenience to the customers (Suraweera et al., 2011).

In Sri Lanka, Commercial banks introduced online banking in 1998s. For the very first time, only five local banks offered online banking facility. They only offered a transactional level to local customers at that time. After the spreading of online banking, state banks also use online banking to compete with rivals. Today state banks and private banks used online banking services in a wider range (Jayasiri, 2008). They offer Online banking, Mobile Banking, E-Statements, Bill payments to provide convenient ways for customers to access bank services \& facilities. (Suraweera et al., 2011)

At present, almost all banks, financial institutes, and service providers provide this facility as a delivery channel to their customers for better provision of their services. These institutes' adoptions vary in scale from very sophisticated applications to simple platforms where only a limited transaction level can be executed. Commercial banks in Sri Lanka use internet banking as a competitive advantage among various other competitive tools to attract a worthwhile customer base and provide better service for the acquired customers. However, the level of e-banking usage in Sri Lanka still remains low compared to the developed, developing, and countries in the region (Suraweera et al., 2011). It has become a critical necessity that Sri Lanka as a nation adopts e-banking activities to compete with the rest of the world. (Jayasiri, 2008)

The rapid spread of technology has made the internet the best channel to provide banking services and products to customers (Kolodinsky, Hogarth, \& Hilgert., 2004). Banks now consider the internet as part of their strategic plan. It will revolutionize the way banks operate, deliver, and compete, especially because the competitive advantages of traditional branch networks are eroding rapidly (Sadeghi \& 
Hanzaee, 2010). Therefore, it is pivotal to identify factors affecting customer adaptation to internet banking.

\subsection{The Rationale of the Research Gap and Intention of the Study}

The banking industry in Sri Lanka plays a vital role in managing financial assets. Conventionally all the banking activities were carried out manually, and customers always had to go to the branch (Suraweera et al., 2011). This has consumed much time and cost to both customers and banks. Internet banking is now rapidly capturing the banking industry by eliminating and transforming conventional banking activities into a web-based online system. (Jayasiri, 2008)

Unfortunately, given these advantages, customers of financial institutions have not completely embraced internet banking. Like other innovations, internet banking faces many obstacles associated with its adoption. Since this technology's success or failure will depend on the rate at which it is adopted, there is a need to determine which factors influence customers to adopt internet banking. (AbuShanab \& Pearson., 2007).

There are 1.3 million credit cards and 17.7 million debit cards in Sri Lanka. Last year, the total value of these digital transactions (excluding POS and ATM withdrawals) was Rs. 270 billion. (Perera, 2017) The author further states, "However, cash is still king. While digital payments are on the rise, cash is still king."

Millennials, identified as those born between 1980 and 2000 and fall between 17 and 37, form approximately $38 \%$ of the population in Sri Lanka and account for most of the working-age population. This segment has become very important to all sectors of the economy, particularly banking and finance (Perera, 2017). Therefore, understanding their needs is crucial for Sri Lanka's financial institutions since it helps build lasting relationships with millennials. Maintaining a sturdy relationship with millennials early on would be beneficial to banks in Sri Lanka since they would eventually progress to saving and making larger investments.

According to a survey carried out by the Department of Census and Statistics Sri Lanka, digital literacy is considered, one out of every three (aged 5 - 69) digital literacy is higher than computer literacy for all disaggregated levels, showing the drift from Personal Computer to Smartphones/Tablets. The study further describes that the highest rate of internet users is millennial's. Persons in the age group 20 - 24 indicate higher internet and email usage than those in other age groups (Perera, 2017).

However, a study by Shiraj (2015) indicates that 72.41 percent of internet banking users who use internet banking in their day to day life being between the ages of 25-45, and 90.91 percent of the customers being between the ages of having just had facilities but not use the internet baking. (Shiraj, 2015). Thereby the current study is carried out to identify the influential factors of low adoption rate 
for internet banking among millennia's by studying undergraduates' adoption on internet banking facilities on various internet applications related to online internet banking. Therefore, the problem statement of the current study can be depicted as below.

Since internet banking penetration is low among millennials, "what are the factors influencing millennials' adoption for internet banking."

\subsection{Purpose of the Study}

In recent years, various well-known theories and models have been employed to explain the relationship between user beliefs, attitudes, and behavioral intentions (BI) to use the technology. From the stream of social psychology, innovation diffusion theory (IDT); theory of reasoned action (TRA); theory of planned behavior (TPB); the social cognitive theory; the motivational model; the model of perceived credibility (PC) utilization; technology acceptance models (TAM) and a hybrid model combining constructs from TAM and TPB, are only a few of the major modular approaches that have to lead the way in analyses and results. (Mun, Jackson, Park, \& Probst, 2006). A review and synthesis of these eight technology use models resulted in the unified theory of acceptance and use of technology (UTAUT) (Venkatesh, Morris, Davis, \& Davis, 2003). Thus, this model becomes one of the most widely used models due to its simplicity, parsimony, and robustness. (Abu-Shanab, Pearson, \& Setterstrom, 2010).

Even though the extensive replication, applications, and integration of UTAUT have enabled many researchers to understand technology adoption, there is still a need for a systematic investigation and theorizing of the salient factors applicable to context-based consumer technology use (Venkatesh, Thong, \& Xu, 2012). Moreover, there is considerable debate among researchers that the UTAUT's constructs may not be sufficient to explain user acceptance of new technology in a voluntary context as the initial UTAUT study focused on large organizations in the business environment that limit its explanatory power (Tarhini. El-Masri, Ali, \& Serrano. 2016).

Moreover, many technologies adoption models, especially the UTAUT2 model, have not been tested in developing countries such as Sri Lanka (Karunanayake. \& Samarasinghe, 2018). Even though many studies have been carried out to understand the factors affecting consumer adoption of internet banking in Sri Lanka, the attention received from prior studies for undergraduates' adoption of internet baking is limited. This study aims to fill this gap by employing the UTAUT2 model (Thilina \& Gunawardane., 2019).

\subsection{Significance of the Concept}

"The Central Bank's challenge is to balance the embracing of the technologic advancements with the banks. We have 26 banks with many brick and mortar, so the journey is to get to a digitalized platform. 
This journey cannot be done swiftly" (Suraweera et al., 2011). The current study is focused on identifying the factors affecting undergraduates' adoption of internet banking facilities. Since the future of the banking practices is expected to expand into the digital arena further, this study would help bank managers and policymakers understand the underline reasons behind the relatively low penetration rate of internet banking in Sri Lanka. Consequently, it will help formulate strategies to encourage the adoption and acceptance of internet banking by Sri Lankan customers.

This paper contributes literature related to theories and models of technology adoption and acceptance, which have recommended to be expanded to new contexts by many researchers. Furthermore, specifically, this study will contribute to the generalizability and applicability of the UTAUT2 in a new context (online banking), new user group (Undergraduates), and new cultural setting (Sri Lanka), which is a critical step to advance a theory.

\section{RESEARCH METHODOLOGY}

This study has followed the literature-based research approach by evaluating the existing empirical evidence. It has also taken the tested factors in a given context to validate the proposed propositions for justifying the variable relationships. It has followed a mixed strategy of the case reveal and literature survey as the said research notion demands a rationale on industry-related perspective. This study follows a deductive approach as it brings the arguments based on existing theories and empirical evidence. Secondary sources have been used as a research tool, and findings are presented as propositions for future studies.

\section{REVIEW OF LITERATURE}

\subsection{Internet Banking}

Online banking is defined as an Internet portal, through which customers can use different kinds of banking services ranging from bill payment to making investments. (Pikkarainen, Pikkarainen, Karjaluoto, \& Pahnila, 2004) The concept of e-banking systems began after installing the first Automated Teller Machines (ATMs) in the 1970s. Electronic banking is also called "Virtual Banking" or "Online Banking" which results from bank customers' developing expectations. It involves information about technology-based banking. This information technology system involves a direct interface with the customers to not visit the bank's premises. Normal banking services covered under online banking is Automated Teller Machines, Credit Cards, Debit Cards, Smart Cards, Electronic Funds Transfer System, Cheques Transaction Payment System, Mobile Banking, Internet Banking, and Telephone Banking. (Madumanthi \& Nawaz, 2016).

Internet banking facilitates bank customers to carry out financial transactions on their own by using a secured internet website operated by the commercial bank, a retail or virtual bank, credit union, or 
building society (Edojariogba, 2014). With the rapid growth of the internet, banks have changed how financial services are being designed and delivered. Internet banking has gradually replaced the traditional based counter-form of banking because it offers many advantages amongst which are: improved efficiency of payment and other financial services, decongesting long queues found within the banking halls and on the part of the banks, it gives room for improvement in building a solid bankcustomer relationship and allows banks' expansion without physically establishing new branches (Adekannbi, 2018).

However, despite the benefits of online banking, traditional banking is still the most accepted way of banking for the majority. According to Pikkarainen, Pikkarainen, Karjaluoto, \& Pahnila (2004), traditional banks have been the vanguard of online banking channel development and control share of the total market.

\subsection{Internet Banking Penetration in Sri Lanka}

The advancement in technology has played an important role in improving service delivery standards in the banking industry. At present, Sri Lanka has a liberalized telecommunications market with a huge impact on the country's economic and social development. The banks' annual reports indicate that the majority of banking customers in Sri Lanka do not use Internet Banking services provided by their banks. When we compare with the development of information and communication technology in the country as pointed out by the Telecommunication and Regulatory Commission of Sri Lanka, Central Bank of Sri Lanka, and the World Bank, the demand for internet banking facilities is not at an exceptional level. (Premarathne \& Gunatilake, 2016).

It is also being mentioned that even by the year 2011, Sri Lanka's internet banking usage was less than $1 \%$ of the banking customers in general, which is a significantly lower usage than that of developed countries. (Suraweera et al., 2011) As per records in the central bank of Sri Lanka, in the year 2012, there were 24 listed commercial banks in Sri Lanka. From that, 12 were local banks that already had the internet banking facility except for Amana bank. (Premarathne \& Gunatilake, 2016) Since now, internet banking is expanding its position from desktop PC to the mobile phone, Sri Lankans still resistant to adopt internet banking is becoming a huge problem. (Suraweera et al., 2011)

\subsection{Factors Influencing Adoption on Internet Banking}

Different studies provide insights into the reasons behind the low penetration of internet banking. To start with, customers need to have access to the internet in order to utilize the service. (Mols, Bukh, \& Nielsen, 1999) Furthermore, new online users need first to learn how to use the service. Second, nonusers often complain that online banking has no social dimension (Mattila, Karjaluoto, \& Pento, 2003). Third, customers have been afraid of security issues (Howcroft, Hamilton, \& Hewer, 2002). The 
other problem consumers experience with the Internet and Internet banking is privacy. This makes security in transactions essential (Liao, Huang, \& Hsieh, 2016). A study showed that trust was directly linked to Internet banking adoption amongst customers, and therefore plays a big role in the adoption process. (Boateng, Adam, Okoe, \& Anning-Dorson, 2016)

Studies have shown that younger segments are more willing to take risks than older segments. Regarding internet banking, the older segments are even more careful than usual (Josefsson, 2017). This makes it important for banks to study how fast the different segments adopt new technology and innovations. These findings indicate that different segments need different kinds of information, i.e., the targeting needs to be customized for each segment to ensure efficiency (Søilen, 2013).

Pasa and Sherman identified ease of use as a critical factor that affects Internet banking usage, while McKecnie, Ganguli, \& Roy (2011) emphasized quality, efficiency, profitability, and overall performance are the determining factors for Internet banking usage. (Perera, 2013) Mansumitrchi \& AL- Malkawi (2011) highlighted eight characteristics of the adoption of IB: difficulty, trust, compatibility, third-party concerns, human contact, social influence, security, and computer proficiency. (Mansumitrchi \& AL-Malkawi, 2011).

Doll found that product information content and its amount of product information, product information format, language, and site layout impact consumers' perception of the user-friendliness of an IB site (Doll, Raghunathan, Lim, \& Gupta, 1995). Guru (2000) argues that designing websites with appropriate use of the graphical user interface is also an important determinant. Further, they concluded that some consumers are generally reluctant to adopt new technology. Thus, technology phobia can also affect customer adoption of internet banking (Guru, 2000).

Another study by Suganthi, Balanchander, \& Balanchandran (2001) finds that educated young people and most affluent populations are more likely to adopt IB. Moreover, this study points out that Internet accessibility, awareness, attitude towards change, computer and Internet access costs, trust in one's bank, security concerns, ease of use, and convenience are the major factors influencing the adoption of IB service. (Suganthi, Balanchander, \& Balanchandran, 2001).

\subsection{Technology Acceptance}

Technology acceptance can be defined as an organization or an individual's decision to utilize and implement the technology (Tatnal \& Burgess, 2009). Unlike the invention of a new technology, which often appears to occur as a single event or jump, the diffusion of that technology usually appears as a continuous and rather slow process. However, it is diffusion rather than invention or innovation that ultimately determines the pace of economic growth and the rate of productivity change. Until many users adopt new technology, it may contribute little to our well-being (Hall \& Khan, 2002). Authors 
further state that diffusion results from a series of individual decisions to begin using the new technology. These decisions are often the result of comparing the uncertain benefits of the new invention with the uncertain costs of adopting it. Understanding the factors affecting this choice is essential both for economists studying the determinants of growth and for the creators and producers of such technologies. If users are unwilling to accept the information system, it will not bring full benefits to the organization (Venkatesh \& Davis, 1996). The more accepting of a new information system the users are, the more willing they are to make changes in their practices and use their time and effort to start using the new information system (Succi \& Walter, 1999).

Various frameworks were proposed to identify the factors or determinants influencing the consumer context's acceptance of the technology. Since online banking is a type of technological innovation, existing studies on innovation adoption could be used to study online banking (Chong, Ooi, lin, \& Tan, 2010).

\subsection{UTAUT Model}

Research in the area of technology acceptance generally has lacked the integrated view needed to understand the domain. The work proposed by Venkatesh, Morris, Davis, \& Davis (2003) integrates previous technology acceptance models into a Unified Theory of Acceptance and Use of Technology (UTAUT). The UTAUT hypothesized four main indicators as influencing behavioral intention and use behavior. These relationships were suggested to be moderated by age, gender, experience, and voluntariness (AbuShanab \& Pearson, 2007).

Anderson, Schwager, \& Kerns (2006) concluded that UTAUT was a useful model in predicting user adoption behaviour. It should be tested in different contexts to validate the proposed relationships further. Moreover, there is considerable debate among researchers who argue that the UTAUT's constructs may not be sufficient to explain user acceptance of new technology in a voluntary context, and the UTAUT study focused on large organizations in the business environment limit its explanatory power (Tarhini, El- Masri, Ali, \& Serrano, 2016).

\subsection{UTAUT2 Model}

As a means of addressing these criticisms, Venkatesh, Thong, \& Xu (2012) proposed UTAUT2 to explain the technology's acceptance and use in a consumer context. A context that represents some specificities compared to the organizational setting (Albugami \& Bellaaj, 2014).

The UTAUT2 model presents seven constructs. Namely, performance expectancy, effort expectancy; social influence; facilitating conditions; hedonic motivation; price value, and habit as determinants of behavioral intention and use of technology by consumers. Besides, three individual differences, such as age, gender, and experience, were added as moderator variables (Albugami \& Bellaaj, 2014). 


\subsection{Application of UTAUT in Sri Lankan Context}

Consumer adoption on internet banking was carefully investigated by many Sri Lankan researchers using UTAUT model. Study conducted by Ayoobkhan revealed that Perceive Usefulness, Perceived Easy to Use, cost, and trust has significant and positive impact on Mobile banking adoption. (Ayoobkhan, 2018) Research by (Madumanthi \& Nawaz, 2016) discovered that performance expectancy, effort

Expectancy, social influence, and bandwidth have a significant positive impact on the behavioral intention to adopt online banking. Furthermore, the authors further state that undergraduates' adoption of online banking has been increased because most undergraduates are aware of IT knowledge, internet experiences, and online banking concepts. (Madumanthi \& Nawaz, 2016). Nevertheless, some areas related to this research need to be investigated and explored further. (Madumanthi \& Nawaz, 2016) Therefore, the researcher will employ the UTAUT2 model to carry out the current study (Venkatesh, Thong, \& Xu, 2012) detected three key constructs that describe the consumer's behavior in the use of technology and the factors included in the UTAUT model: hedonic motivation, price value, and habit.

The current study will investigate the impact these factors impose on consumer intention to adopt online banking. Hedonic motivation is defined as the fun or pleasure derived from using a technology, and it has been shown to play an important role in determining technology acceptance and use (Brown \& Venkatesh, 2005). However, hedonic goods are often used for experimental purpose, fun, joy, and excitement like games, smartphones, and luxury watches (Strahilevitz \& Myers, 1998). Hence the researcher will only study the influence of price value and habit apart from impact of performance expectancy, effort expectancy, social influence, facilitating conditions on undergraduates' adoption on internet banking. By extending the UTAUT to include these two factors, a more comprehensive theoretical perspective of user technology acceptance in the context of internet banking will be provided (Tarhini, El-Masri, Ali, \& Serrano, 2016).

\section{THEORIZATION OF THE RESEARCH PROBLEM}

As for the current research study, the researcher will focus on the Unified Theory of Technology Acceptance and Use 2 (Venkatesh, Thong, \& Xu, 2012) which is the underpinning theory to identify the factors affecting consumer adoption of new technology. While paying attention to the current research context, the researcher will modify the theoretical models to have a better research model explanation.

The search for novelty and innovation can be added to hedonic motivation when using ICT. However, when the experience increases, the novelty's attractiveness, which contributes to hedonic motivation, can diminish, and the consumers will use the ICT with more practical intentions (Venkatesh, Thong, \& 
$\mathrm{Xu}, 2012)$. In the case of a technology in which utilitarian and hedonic benefits exist, both will be important determinants of its use. However, if the technology is more oriented toward the hedonic value, this will have a greater impact on adopting it (Heijden, 2004). However, there is no apparent orientation towards hedonic benefits nor the technology can be considered an innovative technology to consumers with regards to internet banking. Therefore, researcher have excluded the hedonic motivation in the model that will be utilized to carry out this study. Besides, this study did not investigate the effect of Gender, Age, or Experience in behavioral intention to use internet banking. The majority of higher education students are of almost the same age and with small variations in technological experiences (Mtebe \& Raisamo, 2014).

\section{PROPOSED RESEARCH PROPOSITIONS}

This research paper endeavours to identify the factors influencing undergraduate's adoption on internet banking. The researcher has identified independent and dependent variables to be studied through the literature review, and below, hypotheses have been developed by referring Unified Theory of Technology Acceptance and Use.

A study done by Venkatesh, Morris, Davis, \& Davis (2003) identified four factors that impact technology intention and usage. Namely, performance expectancy, the degree to which an individual is looking forward uses technology or the technological product to attain the desired goal. Effort expectancy; the extent to which easiness is associated with using the system or a technological product. Facilitating conditions; the extent to which an individual is looking forward that the technical infrastructure exists to support technological product use. Social influence; the extent to which an individual believes that others are looking forward, that they should use the new technological product.

UTAUT2 presented to explain the acceptance and use of technology in a consumer context. A context that represents some specificities compared to the organizational setting. Thereby, Venkatesh, Thong, and $\mathrm{Xu}$ (2012) introduced additional constructs, added new relationships, and deleted one construct from their original model. Compared to UTAUT, the extensions proposed in UTAUT2 produced a substantial improvement in the variance explained of technology use (Albugami \& Bellaaj, 2014). This paper employs the UTAUT2 model with few modifications and is depicted below as proposed propositions.

As this paper focuses on the acceptance of internet banking, there is a need to revisit the validity of the antecedents used in the UTAUT2 for a better explanation of the current context. In the UTAUT, though hedonic motivation has been used as an antecedent, this study has identified a lack of suitability in the model as far as the current context and technology are concerned. Hedonic goods are often used for experimental purposes, fun, and excitement, like games, smartphones, and luxury watches (Strahilevitz 
\& Myers, 1998). In contrast to hedonic values, utilitarian values have more relevance to this context (Karunanayake \& Samarasinghe, 2018).

\subsection{Performance Expectancy}

Performance expectancy is defined as the degree to which Internet banking will benefit consumers in performing certain activities. Venkatesh, Thong, \& Xu, (2012) composing performance expectancy, the UTAUT summed or aggregated all job/performance-related constructs. Aspects like usefulness, job fit, and relative advantage are important for individuals when deciding on using/adopting a technology (Pearson \& AbuShanab, 2007).

Performance expectancy is similar to the perceived usefulness of TAM and the relative advantage of innovation diffusion theory (Venkatesh, Morris, Davis, \& Davis, 2003). Based on the findings of preceding studies, it is probable that performance expectancy will have a significant and positive relationship with behavioral intention to use internet banking among Sri Lankan undergraduates. A study carried out by Pearson and Abushanab revealed that Performance expectancy accounted for the largest unique contribution in explaining behavioral intention variance. Customers with highperformance expectancy had high intentions to use internet banking (Pearson \& AbuShanab, 2007). In the Sri Lankan context, Madumanthi and Nawas (2016), discovered that Performance Expectancy has a significant positive impact on the behavioral intention to adopt online banking. This suggests that if the undergraduates realize the benefits of their online banking services, more will adopt the system (Madumanthi \& Nawaz, 2016). Hence, the following proposition was developed by the researcher.

\section{P1: performance expectancy has a positive effect on undergraduates' adoption on Internet banking.}

\subsection{Effort Expectancy}

Effort expectancy can be defined as "the degree of ease associated with the use of a system" (Venkatesh, Morris, Davis, \& Davis, 2003). UTAUT model suggests that effort expectancy has a positive influence on consumer intention to adopt new technology. In other words, UTAUT propose if the users found internet banking services easy to use, and do not require much effort, then they are more likely to adopt it (Tarhini, El-Masri, Ali, \& Serrano, 2016).

In a global context, the UTAUT model was used numerous times to examine consumer adoption on internet banking. It has been consistently confirmed that both performance expectancy and effort expectancy are the most important predictors of the intention to use. Foon and Fah's study affirmed a significant relationship between performance expectancy, effort expectancy, and consumer adoption of internet baking (Foon \& Fah, 2011). Furthermore, it was further confirmed in the Sri Lankan context by Nawaz and Yamin (2018). They discovered that customers would like to use m-banking services if 
they realize that such systems' usage is not difficult and does not require extra effort and energy (Nawaz \& Yamin, 2018). Thus, the researcher proposes the following.

\section{P2: effort expectancy has a positive effect on undergraduates' adoption on Internet banking}

\subsection{Social Influence}

Social influence has been defined as "the degree to which an individual customer perceives that important of others believe he or she should use the technological product (Venkatesh, Morris, Davis, \& Davis, 2003) is similar to the social norm in TRA, TAM2, and TPB; and image in IDT. Social influence refers to the social pressure coming from the external environment that surrounds the individuals. It may affect their perceptions and behaviors of engaging in a certain action, such as friends, relatives, and superiors' opinions (Tarhini, El-Masri, Ali, \& Serrano, 2016; Wanninayake, W.M.C.B, 2014; Chovancova \& Wanninayake, 2012).

Giving empirical evidence into the connection between performance intention and social influence, Madumanthi and Nawas empirically proven that Social Influence has a significant positive impact on clarifying undergraduates' Behavioral Intention to adopt online banking services. (Madumanthi \& Nawaz, 2016) Accordingly, the researcher postulates the following proposition.

\section{P3: Social influence has a positive effect on undergraduates' adoption on Internet banking}

\subsection{Facility Conditions}

The FC has been defined as "the degree to which an individual believes that an organizational and technical infrastructure exists to support the use of the system" (Venkatesh, Morris, Davis, \& Davis, 2003). Internet banking can be bandwidth, IT literacy, smart devices, desktop computers, or any other device that can be used to connect to the internet.

This concept is similar to perceived behavioral control of TPB, which reflects the degree to which an individual feel that performing a behavior is under his volitional control. The users of Internet banking need to have, for example, certain computer skills and IT knowledge for using e-banking services (MoezBellaaj \& Albugami, 2014). According to UTAUT2, facilitating conditions directly impact behavioral intention, and previous research reveals its positive impact on the intention to use Internet banking (Nasri \& Charfeddine, 2012). It is further proven in the internet banking context by a study conducted by Tarhini, El-Masiri, Ali and Serrano (Tarhini, El-Masri, Ali, \& Serrano, 2016). Thus, the researcher proposes the following.

P4: Facility Conditions have a positive effect on undergraduates' adoption on Internet banking. 


\subsection{Price Value}

"Price Value" is defined as consumers' cognitive trade-off between the applications' perceived benefits and the financial cost for using a particular product or service (Venkatesh, M.G.Morris, Davis, \& Davis, 2003). According to a study carried out by Yu, Price value affects behavioral intention toward adopting internet banking. (Yu, 2012) A study further confirmed this carried out by Hettiarachchi in the Sri Lankan context, which explains that the greater the relative advantage of using internet banking services, the more likely that internet banking will be adopted can be accepted (Hettiarachchi, 2013). Accordingly, the researcher postulates the following proposition.

P5: Price value has a positive effect on undergraduates' adoption on Internet banking

\subsection{Habit}

Literature defines a habit as the extent to which people tend to perform behaviors automatically because of learning (Venkatesh, Thong, \& Xu, 2012). Arenas-Gaitán, Peral-Peral, and Ramón-Jerónimo have recognized that habit has a direct effect on internet banking use, and habit limits the strength of the relationship between behavioral intention and the elderly's internet banking use (Arenas-Gaitán, PeralPeral, \& Ramón-Jerónimo, 2011). Hettiarachchi (2013) confirms this further by stating, "The greater the self-efficacy toward using internet banking, the more likely that internet banking will be adopted can be accepted". Thus, the researcher proposes the following.

P6: Habit has a positive effect on undergraduates' adoption on Internet banking.

\section{CONCEPTUAL FRAMEWORK}

Figure 1: Conceptual Framework

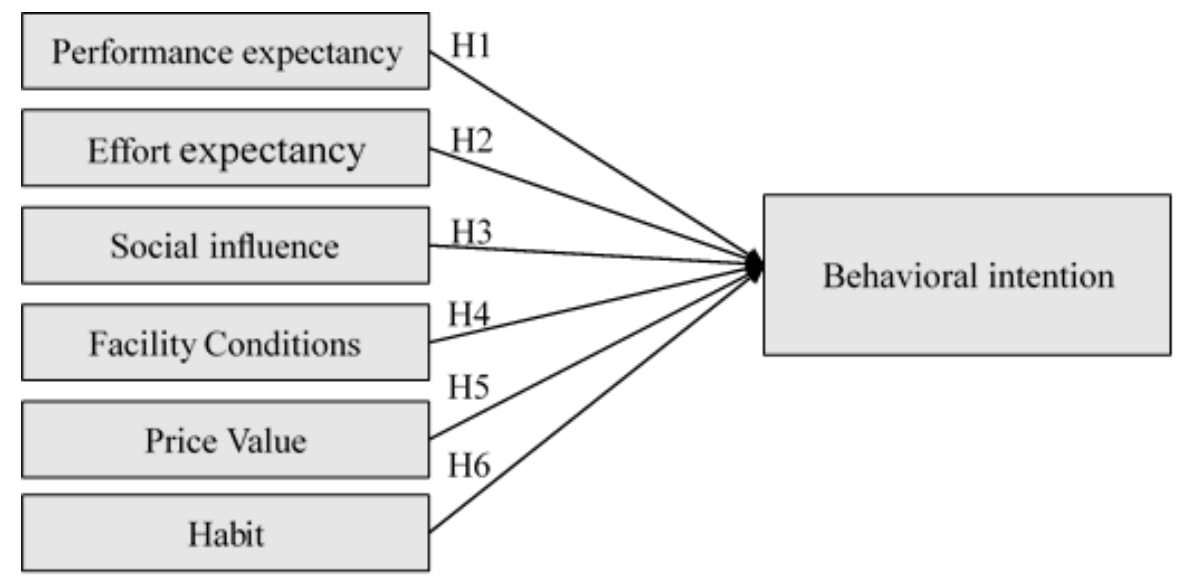




\section{CONCLUSION AND DIRECTION FOR FUTURE RESEARCH}

As per arguments and discussions made in this paper, suggested propositions can be conceptualized with two main concepts called 'Consumer Buying Intention' and "Purchase intention determinants." In line with this, future studies are encouraged to hypothesize how the other factors can impact undergraduates' adoption of online banking services, such as type of Internet connection used, selfefficiency, culture, and trust.

\section{REFERENCES}

AbuShanab, E., \& Pearson, J. M. (2007). Internet banking in Jordan: The unified theory of acceptance and use of technology (UTAUT) perspective. Journal of Systems and Information Technology, 9(1), 78-97

AbuShanab, E., Pearson, J. M., \& Setterstrom, A. J. (2010). Internet banking and customers' acceptance in Jordan: the unified model's perspective. Communications of the Association for Information Systems, 26(1), 23.

Adekannbi, J. O. (2018). Relationship between orthodox and traditional medical practitioners in the transmission of traditional medical knowledge in Nigeria. Health Information \& Libraries Journal, 35(2), 130-140

Albugami, M., \& Bellaaj, M. (2014). the continued use of internet banking-combining UTAUT2 theory and service quality model. Journal of Global Management Research, 10(1), 11-28

Anderson, J. E., Schwager, P. H., \& Kerns, R. L. (2006). The drivers for acceptance of tablet PCs by faculty in a college of business. Journal of Information Systems Education, 17(4), 429

Arenas Gaitán, J., Peral Peral, B., \& Ramón Jerónimo, M. (2015). Elderly and internet banking: An application of UTAUT2. Journal of Internet Banking and Commerce, 20(1), 1-23

Ayoobkhan, A. L. M. (2018). Factors contributing to the adoption of mobile banking in Sri Lanka: special reference to Sampath Bank in Ampara district, International Journal of Latest Engineering and Management Research, $3(8), 47-57$

"Boateng, H., Adam, D. R., Okoe, A. F., \& Anning-Dorson, T. (2016). Assessing the determinants of internet banking adoption intentions: A social cognitive theory Perspective. Computers in Human Behavior, 65, 468-478

Brown, S. A., \& Venkatesh, V. (2005). A model of adoption of technology in the household: A baseline model test and extension incorporating household life cycle. Management Information Systems Quarterly, 29(3), 11.

Chovancova, M., Asamoah, E. S., Wanninayake, W.M.C.B (2012), Consumer Behaviour and Branding: A cross Cultural Perspectives, GEORG Zilina, Bojzova11, 01001, Zilina, Slovak Republic.

Doll, W. J., Raghunathan, T. S., Lim, J. S., \& Gupta, Y. P. (1995). A confirmatory factor analysis of the user information satisfaction instrument. Information Systems Research, 6(2), 177-188.

Foon, Y. S., \& Fah, B. C. Y. (2011). Internet banking adoption in Kuala Lumpur: an application of UTAUT model. International Journal of Business and Management, 6(4), 161

Guru, B., Vaithilingam, S., Ismail, N. and Prasad, R. (2000), "Electronic Banking in Malaysia: A Note onEvolution of Services and Consumer Reactions." Journal of Internet Banking and Commerce, 5(1)

Hall, B. H., \& Khan, B. (2002). Adoption of New Technology. New Economy Handbook 
Howcroft, B., Hamilton, R., \& Hewer, P. (2002). Consumer attitude and the usage and adoption of home-based banking in the United Kingdom. International journal of Bank Marketing, 20(3), 111-121.

Jayasiri, N. K. (2008). Popularity of Electronic Banking in Sri Lanka. Proceedings of the 3 rd International Research Conference on Management and Finance.

Josefsson, T. (2017). Internet banking and the Technology Acceptance Model: The role of trust, International Marketing Programme, Halmstad University, Halmstad, Sweden"

Karunanayake, T., \& Samarasinghe, D. (2018). The Effect of Perceived Risk on the Purchase Intention of Alternative Fuel Vehicles, Sri Lankan Journal of Management, 23(2), 67-98

Kolodinsky, J. M., Hogarth, J. M., \& Hilgert, M. A. (2004). The adoption of electronic banking technologies by US consumers. International Journal of Bank Marketing, 22(4), 238-259

Liao, C., Huang, Y. J., \& Hsieh, T. H. (2016). Factors influencing internet banking adoption. Social Behavior and Personality: An International Journal, 44(9), 1443-1455.

Madumanthi, I., \& Nawaz, S. S. (2016). Undergraduates' adoption of online banking in Sri Lanka, Journal of Information Systems \& Information Technology (JISIT), 1(1), 10-17

Madumanthi, I., \& Nawaz, S. S. (2016). Undergraduates' adoption of online banking in Sri Lanka. Journal of Information Systems \& Information Technology, 1(1), 10-17

Mansumitrchai, S., \& Al-Malkawi, H. A. N. (2011). Factors underlying the adoption of online banking by Mexican consumers. International Journal of Business and Management, 6(9), 155.

Mattila, M., Karjaluoto, H., \& Pento, T. (2003). Internet banking adoption among mature customers: early majority or laggards?. Journal of Services Marketing, 17(5), 514-528.

McKecnie, S., Ganguli, S., \& Roy, S. K. (2011). Generic technology-based service quality dimensions in banking. International Journal of Bank Marketing.

Mols, N. P., Nikolaj D. Bukh, P., \& Flohr Nielsen, J. (1999). Distribution channel strategies in Danish retail banking. International Journal of Retail \& Distribution Management, 27(1), 37-47.

Mtebe, J., \& Raisamo, R. (2014). Investigating students' behavioural intention to adopt and use mobile learning in higher education in East Africa. International Journal of Education and Development using ICT, 10(3).

Mun, Y. Y., Jackson, J. D., Park, J. S., \& Probst, J. C. (2006). Understanding information technology acceptance by individual professionals: Toward an integrative view. Information \& Management, 43(3), 350-363.

Nasri, W., \& Charfeddine, L. (2012). Motivating salespeople to contribute to marketing intelligence activities: An expectancy theory approach. International Journal of Marketing Studies, 4(1), 168.

Nawaz, S.S. and Yamin, F.B.M. (2018), "Sri Lankan customers' behavioural intention to use mobile banking: a structural equation modelling approach", Journal of Information Systems \& Information Technology, 2(2). 1-14

P.Edojariogba. (2014). Electronic Banking Channels and Customers' Preferences. Research Dissertation Submitted to the Department of Business Administration University of Benin, Nigeria

Perera, L. (2017). Digital Transactions in Sri Lanka Expected to Hit Rs. 300Billion. Retrieved from Readme: https://www.readme.lk/sri-lanka-digital-transactions/

Pikkarainen, T., Pikkarainen, K., Karjaluoto, H., \& Pahnila, S. (2004). Consumer acceptance of online banking: an extension of the technology acceptance model. Internet research, 14(3), 224-235 
Pikkarainen, T., Pikkarainen, K., Karjaluoto, H., \& Pahnila, S. (2004). Consumer acceptance of online banking: an extension of the technology acceptance model. Internet research, 14(3), 224-235.

Premarathne, W., \& Gunatilake, M. M. (2016). Consumer Adoption of Internet Banking in Sri Lanka. International Journal of Advanced Research, 4(11), 758-765

Sadeghi, T., \& Heidarzadeh Hanzaee, K. (2010). Customer satisfaction factors (CSFs) with online banking services in an Islamic country: IR Iran. Journal of Islamic Marketing, 1(3), 249-267.

Seelanatha, L. (2010). Market structure, efficiency and performance of banking industry in Sri Lanka. Banks and Bank Systems, 5(1), 20-31.

Shiraj, M. M. (2015). Factors Influencing the Adoption of Internet Banking:(Special Reference to the South Eastern Region, Sri Lanka). In Second International Symposium-2015, South-Eastern University of Sri Lanka (pp. 183190).

Söilen, K. S. (2013). Editorial note 2013 Vol 3 No 2. Journal of Intelligence Studies in Business, 3(2).

Strahilevitz, M., \& Myers, J. G. (1998). Donations to charity as purchase incentives: How well they work may depend on what you are trying to sell. Journal of consumer research, 24(4), 434-446.

Succi, M. J., \& Walter, Z. D. (1999, January). Theory of user acceptance of information technologies: an examination of health care professionals. In Proceedings of the 32nd Annual Hawaii International Conference on Systems Sciences. 1999. HICSS-32. (pp. 7-pp). IEEE.

Suraweera, T., Kahingala, S., Batepola, A., Punchihewa, M., Senevirathna, K., \& Kahandawaarachchi, C. (2011). IT Driven Banking Services in Sri Lanka: Customer Acceptance and Service Quality

Tarhini, A., El-Masri, M., Ali, M., \& Serrano, A. (2016). Extending the UTAUT model to understand the customers' acceptance and use of internet banking in Lebanon: A structural equation modeling approach. Information Technology \& People, 29(4), 830-849

Tatnall, A., \& Burgess, S. (2009). Adoption Of E-Commerce in SMEs. In Encyclopedia of Information Science and Technology, Second Edition (pp. 41-45). IGI Global.

Thilina, D., \& Gunawardane, N. (2019). The effect of perceived risk on the purchase intention of electric vehicles: an extension to the technology acceptance model. International Journal of Electric and Hybrid Vehicles, 11(1), 7384.

Van der Heijden, H. (2004). User acceptance of hedonic information systems. MIS quarterly, 695-704.

Venkatesh, V., \& Davis, F. D. (1996). A model of the antecedents of perceived ease of use: Development and test. Decision sciences, 27(3), 451-481.

Venkatesh, V., Morris, M. G., Davis, G. B., \& Davis, F. D. (2003). User acceptance of information technology: Toward a unified view. MIS quarterly, 425-478.

Venkatesh, V., Thong, J. Y., \& Xu, X. (2012). Consumer Acceptance and Use of Information Technology: Extending the Unified Theory of Acceptance and Use of Technology. MIS quarterly, 36(1), 157-178.

Wanninayake, W.M.C.B, (2014). Consumer Ethnocentrism as a Strategic Tool for Developing Domestic Brand Equity in Developing Countries. Proceedings of the Annual Research Symposium, (pp 139-142), National Centre for Advanced Studies. ISBN 978-955-4978-00-3.

Yee-Loong Chong, A., Ooi, K. B., Lin, B., \& Tan, B. I. (2010). Online Banking Adoption: An Empirical Analysis. International Journal of Bank Marketing, 28(4), 267-287 